INTERNATIONAL JOURNAL OF MULTidisciplinARY RESEARCH AND ANALYSis

ISSN(print): 2643-9840, ISSN(online): 2643-9875

Volume 04 Issue 11 November 2021

DOI: 10.47191/ijmra/v4-i11-43, Impact Factor: 6.072

Page No.- $1748-1756$

\title{
Forecasting of Tourism Processes in Uzbekistan in Correlation- Regression Models
}

\section{F.E. Gulmurodov}

Doctor of Philosophy in Technical Sciences, Senior Lecturer, Samarkand State Institute of Architecture and Construction

ABSTRACT: The article provides detailed information on the process of developing effective plans for the development of the tourism industry and choosing the optimal one based on them, forecasting the future development of the industry. It also considers the processes of using special computational and arithmetic methods that allow predicting the events and happenings in the tourism industry, to determine the regression function as a result of the interaction and interaction of indicators representing the type of activity. As a result of targeted research, using correlation-regression models, a forecast of the development trend of the tourism industry based on socio-economic factors affecting the tourism process was developed.

KEYWORDS: Prediction, model, correlation-regression models, Fisher criterion, correlation coefficient, Determination coefficient, multicollinearity.

\section{INTRODUCTION}

Development of the economy in the country, in particular, tourism, maximum satisfaction of tourism needs of the population, preservation of ecological balance and cultural heritage in the integrated development of the regions, ensuring sustainable development of tourism, steady increase in budget revenues from tourism; Extensive measures are being taken to establish promising tourism centers, increase the level of development of excursions, develop rural tourism, improve the information and advertising of regional tourist and recreational activities, and achieve certain results.

\section{THE MAIN FINDINGS AND RESULTS}

The development of effective plans for the development of the tourism industry in the Republic of Uzbekistan and the selection of optimal ones based on them is directly related to the process of forecasting the future development of the industry. This process involves the use of special computational and arithmetic methods that allow predicting the events and happenings in the tourism industry, to determine the regression function as a result of the interaction and interaction of indicators representing the tour activity. Scientific research on forecasting the development of socio-economic processes was carried out by foreign and domestic scientists A.Dimitrios [3], G.Stephen [3], I.I.Eliseevoy [4], A.V.Kostromin [6], M.T.Alimova [1,2], F.E. Gulmurodov [5] and others. As a result of targeted research, special attention was paid to hotels, the number of places in them, the quality of services and tour operators, among many factors affecting the tourism process.

Table 1. The number of foreign citizens and domestic tourists visiting Uzbekistan and the factors affecting them (The table is based on the data of the Committee for Tourism Development of the Republic of Uzbekistan.)

\begin{tabular}{|l|l|l|l|l|l|l|l|}
\hline № & Кўрсаткичлар & 2014 & 2015 & 2016 & 2017 & 2018 & 2019 \\
\hline 1 & $\begin{array}{l}\text { Foreign citizens arriving } \\
\text { in Uzbekistan } \\
\text { (thousand people) }\end{array}$ & 2000 & 2010 & 2070 & 2690 & 5300 & 6748 \\
\hline 2 & $\begin{array}{l}\text { Export of tourist } \\
\text { services } \\
\text { dollars) }\end{array}$ & 324 & 386 & 547 & 1040 & 1313 \\
\hline 3 & Number of domestic & 4100 & 5700 & 6300 & 9800 & 14300 & 16900 \\
\hline
\end{tabular}


Forecasting of Tourism Processes in Uzbekistan in Correlation-Regression Models

\begin{tabular}{|l|l|l|l|l|l|l|l|}
\hline & $\begin{array}{l}\text { tourists (visits, } \\
\text { thousands) }\end{array}$ & & & & & & \\
\hline 4 & $\begin{array}{l}\text { Number of hotels (in } \\
\text { units) }\end{array}$ & 428 & 514 & 689 & 772 & 914 & 1188 \\
\hline 6 & $\begin{array}{l}\text { Number of places } \\
\text { (thousand) }\end{array}$ & 19 & 24 & 30 & 39 & 41 & 53 \\
\hline 7 & $\begin{array}{l}\text { Tour operators } \\
\text { (together) }\end{array}$ & 80 & 91 & 102 & 127 & 234 & 499 \\
\hline
\end{tabular}

The above graphs show the dynamics of changes in the number of foreign citizens and the number of domestic tourists visiting Uzbekistan in 2014-2019:

In order to carry out this research, it is necessary to determine the dynamics of changes in the number of foreign citizens and domestic tourists visiting Uzbekistan on the basis of Table 1 and the factors influencing it, and to select the most important factors using correlation-regression methods.

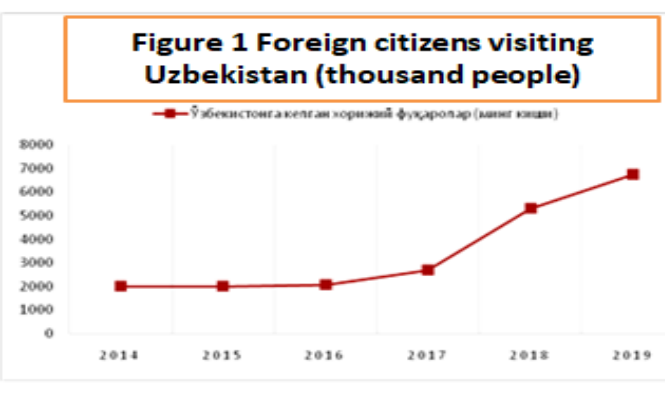

Figure 1 Foreign citizens visiting Uzbekistan (thousand people)

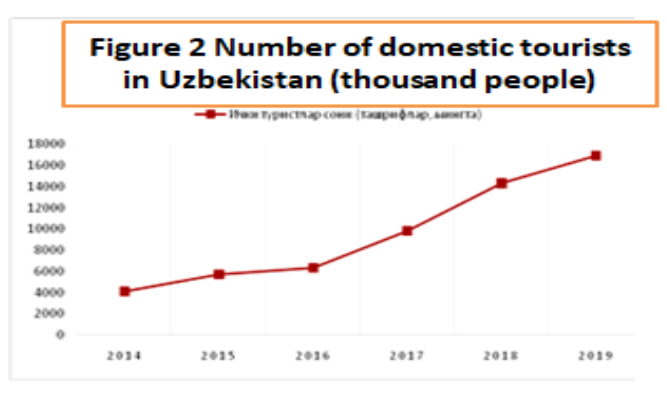

Figure 2 Number of domestic tourists in Uzbekistan (thousand people)

In a multi-factor correlation-regression model, several factors are involved, and it is important to correctly select the most important of these factors and incorporate them into the regression model. The correct selection of important factors and its interdependence is done in three stages. In the first stage, the factors are selected without any conditions. In the second stage, they analyze the bond density on the basis of double correlation. To do this, and a pair of correlation values between the variables, their matrix is constructed. In the third stage, a regression model is constructed and the quality of its parameters is determined using statistical methods.

The first stage. Exports of tour operators and tourist services were selected as factors influencing the outcome factor of the number of foreign citizens visiting Uzbekistan. The number of hotels, the number of places, tour operators were selected as factors influencing the outcome factor of the number of domestic tourists.

These outcome factors and the factors influencing it were identified in the following order:

Table 2

\begin{tabular}{|l|c|}
\hline Factor: Number of foreign citizens visiting Uzbekistan, thousand people $-Y_{1}$ & Marking \\
\hline Factors & $X_{1}$ \\
\hline Exports of tourist services, mln & $X_{2}$ \\
\hline Tour operators, together & \\
\hline
\end{tabular}

Table 3

\begin{tabular}{|l|c|}
\hline Outcome factor: Number of domestic tourists in Uzbekistan, thousands of visits & Marking \\
\hline Factors & $X_{3}$ \\
\hline Number of hotels, in units & $X_{4}$ \\
\hline Number of places, thousand & $X_{5}$ \\
\hline Tour operators, together & \\
\hline
\end{tabular}




\section{Forecasting of Tourism Processes in Uzbekistan in Correlation-Regression Models}

The second stage. The value of the double correlation coefficient between variables $x_{i}$ and $y_{i}, i=1, \ldots, n$ is calculated according to the following formula:

$$
r_{i j}=\frac{\left(\sum x_{i} x_{j}-\sum x_{i} \times \sum x_{j} / n\right)}{\sqrt{\left(\sum x_{i}^{2}-\left(\sum x_{i}\right)^{2} / n\right)\left(\sum x_{j}^{2}-\left(\sum x_{j}\right)^{2} / n\right)}}
$$

Based on formula 1, we calculate the double correlation coefficients between the factors and construct their matrix.

The values of the correlation coefficients between the resultant factor and the factors influencing the number of foreign citizens visiting Uzbekistan are given in Table 4.

Based on the analysis of the data in Table 4, it can be said that the result factor is a strong direct link between the number of domestic tourists in Uzbekistan $\left(Y_{2}\right)$ and exports of tourist services $\left(X_{1}\right)$ and tour operators $\left(X_{2}\right)$.

The values of the correlation coefficients between the resultant factor of the number of domestic tourists in Uzbekistan and the factors influencing it are given in Table 5.

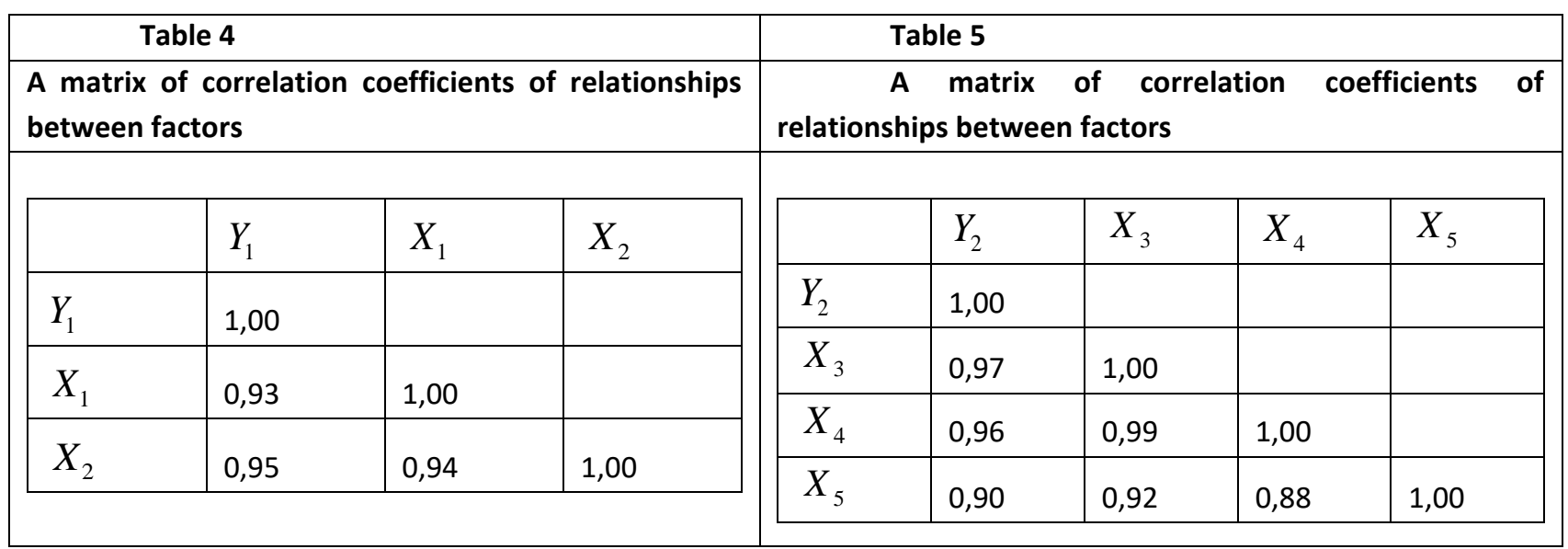

Based on the analysis of the data in Table 5, it can be said that there is a strong direct correlation between the number of foreign nationals visiting Uzbekistan $\left(Y_{1}\right)$ and the number of hotels $\left(X_{3}\right)$, number of places $\left(X_{4}\right)$ and tour operators $\left(X_{5}\right)$.

The third stage. We proposed the use of a multivariate regression linear model for prognosis. This model has the following general appearance:

$$
y=a_{0}+\sum_{i=1}^{m} a_{i}\left(x_{i}\right)
$$

where $a_{0}$ - release limit, $a_{1}, a_{2}, \ldots, a_{n}$ - multifactor model parameters, - result factor; $x_{1}, x_{2}, \ldots, x_{n}$ - Influencing factors.

(2) To find the values of the unknown $a_{0}, a_{1}, \ldots, a_{n}$ parameters in the model, a system of equations is constructed as follows. Based on the solution of this system of equations, the values of $a_{0}, a_{1}, \ldots, a_{n}$ parameters are determined [4]:

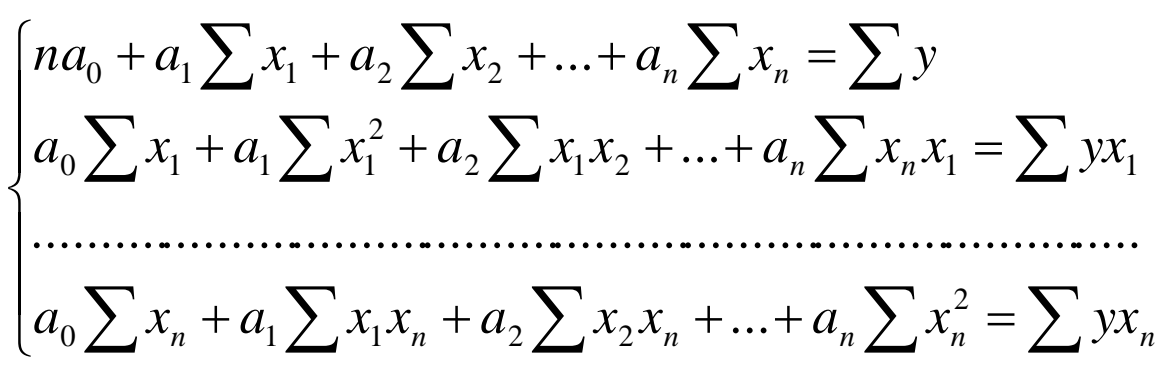




\section{Forecasting of Tourism Processes in Uzbekistan in Correlation-Regression Models}

In the constructed regression model, the coefficient of determination $\left(R^{2}\right)$ is used to determine the density of the correlation of the resulting factor with the selected factors. This figure is calculated on the basis of the following formula:

$$
R^{2}=1-\frac{\sum_{i=1}^{n}\left(y_{i}-\hat{y}_{i}\right)^{2}}{\sum_{i=1}^{n}\left(y_{i}-\bar{y}\right)^{2}}
$$

where $y_{i}$ is the observed amount of the resulting factor; $\bar{y}$ - arithmetic mean of the resulting factor; $\hat{y}$ - determined, flattened quantities of the resulting factor; $n$ - number of observations.

The coefficient of determination represents the proportion of the resulting variable variance of the factors affected by the constructed model. The analysis of the quality of the built model is carried out by checking the "zero hypothesis". The "null hypothesis" determines the overall quality of the coefficients of the regression model. If the results of the analysis do not refute the "zero hypothesis", then it is concluded that "the effect of factors $x_{1}, x_{2}, \ldots, x_{k}$ on the resultant indicator " $y$ " is insignificant, the overall quality of the regression equation is low." The "zero hypothesis" is tested using variance analysis, and

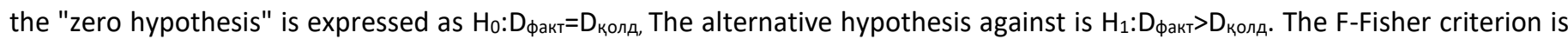
used to test these hypotheses [1].

The actual value of the Fisher criterion is calculated by the following formula:

$$
F=\frac{\sum_{i=1}^{n}\left(\hat{y}_{i}-\bar{y}\right)^{2} / k}{\sum_{i=1}^{n}\left(y_{i}-\hat{y}_{i}\right)^{2} /(n-k-1)}=\frac{R^{2}}{1-R^{2}} * \frac{(n-k-1)}{k}
$$

where $\sum_{i=1}^{n}\left(\hat{y}_{i}-\bar{y}\right)^{2} / k$ is the factorial variance per one degree of freedom (number of degrees of freedom; 2 is the number of residual variances per degree of freedom $\gamma 1=\mathrm{k}) ; \sum_{i=1}^{n}\left(y_{i}-\hat{y}_{i}\right)^{2} /(n-k-1)$ is the number of observations $\left.\gamma 1=\mathrm{n}-\mathrm{k}-1\right) ; \mathrm{n}$ is the number of factors (parameters) in the multivariate regression equation).

The true value of the Fisher criterion is compared with the critical value of the criterion $\left(F_{\operatorname{tab}}(\alpha ; k ; n-k-1)\right)$. If $F_{\text {real }}$ is a real $>\mathrm{Ftab}$ table, then the defined model is significant [4].

The following results (Tables 6-9) were obtained using the SPSS program to perform the above calculations.

Table 6. Results of multifactor linear model parameters (Number of foreign citizens visiting Uzbekistan)

\begin{tabular}{|l|l|l|l|l|l|}
\hline & \multicolumn{2}{|l|}{ Non-standardized coefficients } & Standardized coefficients & t- statistics & Probability \\
\cline { 2 - 6 } & Coefficient & Default error & Бета & & \\
\hline$a_{0}$ & 438,99 & 1469,407 & & 0,009 & 0,993 \\
\hline$X_{1}$ & 4,204 & 3,041 & 0,354 & 0,861 & 0,453 \\
\hline$X_{2}$ & 1,596 & 5,194 & 0,624 & 1,520 & 0,226 \\
\hline
\end{tabular}

Table 7. Criteria for checking the quality and relevance of a multifactor linear model (Number of foreign citizens visiting Uzbekistan)

\begin{tabular}{|l|l|l|l|l|}
\hline $\begin{array}{l}\text { Multifactor correlation } \\
\text { coefficient } \\
\mathbf{R}\end{array}$ & $\begin{array}{l}\text { The multifactor determination } \\
\text { coefficient is R-square }\end{array}$ & $\begin{array}{l}\text { Correction- } \\
\text { resurrected } \\
\text { R-square }\end{array}$ & $\begin{array}{l}\text { Standard error of } \\
\text { evaluation }\end{array}$ & F-real \\
\hline 0,99 & 0,98 & 0,96 & 988,30 & 65,933 \\
\hline
\end{tabular}




\section{Forecasting of Tourism Processes in Uzbekistan in Correlation-Regression Models}

Here the related variable is: $Y$; method: smallest squares; selection: 2014-2019 years number of observations: 6 Based on the data in Tables 6-7 and Formula 2, we write the appearance of a multivariate linear model as follows:

$$
Y_{1}=438.991+4.204 \cdot x_{1}+1.596 \cdot x_{2}
$$

This multi-factor linear model shows that if the export of tourist services $\left(X_{1}\right)$ increases by an average of $\$ 1$ million, the number of foreigners visiting Uzbekistan will increase by $4,204,000$. The increase in the number of tour operators by an average of one will lead to an increase in the number of foreigners visiting Uzbekistan by 1,596 .

Table 8. Results of multifactor linear model parameters (Number of domestic tourists in Uzbekistan)

\begin{tabular}{|c|c|c|c|c|c|}
\hline & \multicolumn{2}{|c|}{ Non-standardized coefficients } & \multirow{2}{*}{$\begin{array}{l}\text { Standardized coefficients } \\
\text { Бета }\end{array}$} & \multirow[t]{2}{*}{ t-statistics } & \multirow[t]{2}{*}{ Probability } \\
\hline & Coefficient & Default error & & & \\
\hline$a_{0}$ & $-3176,865$ & 4033,178 & & $-0,788$ & 0,513 \\
\hline$X_{3}$ & 7,823 & 28,085 & 0,421 & 0,279 & 0,807 \\
\hline$X_{4}$ & 174,255 & 520,258 & 0,423 & 0,335 & 0,770 \\
\hline$X_{5}$ & 4,434 & 15,462 & 0,140 & 0,287 & 0,801 \\
\hline
\end{tabular}

Table 9. Criteria for checking the quality and importance of the multifactor linear model (number of domestic tourists in Uzbekistan)

\begin{tabular}{|l|l|l|l|l|}
\hline $\begin{array}{l}\text { Multifactor correlation } \\
\text { coefficient R }\end{array}$ & $\begin{array}{l}\text { The multifactor determination } \\
\text { coefficient is R-square }\end{array}$ & $\begin{array}{l}\text { Correction-resurrected } \\
\text { R-square }\end{array}$ & $\begin{array}{l}\text { Standard error of } \\
\text { evaluation }\end{array}$ & $\begin{array}{l}\text { F- } \\
\text { real }\end{array}$ \\
\hline 0,97 & 0,94 & 0,85 & 1987,396 & 10,45 \\
\hline
\end{tabular}

Here the related variable is: Y; method: smallest squares; selection: 2014-2019 number of observations: 6

Based on the data in Tables 8-9 and Formula 2, we write the appearance of the second multivariate linear model as follows:

$$
Y_{2}=-3176,865+7.823 \cdot x_{3}+174.255 \cdot x_{4}+4.434 \cdot x_{5}
$$

This multi-factor linear model shows that an increase in the number of hotels $\left(X_{1}\right)$ by an average of one leads to an increase in the number of domestic tourists by 7,800 , an increase in the number of domestic tourists by an average of 17,425 , and an increase in the number of domestic tourists by 4,434 .

The coefficient of determination $R^{2}$ of the first resultant factor in the results is 0.98 , which indicates that the resultant factor is sufficiently closely related to the selected factors, i.e. the number of foreigners visiting Uzbekistan ( $\left.Y_{2}\right) 94 \%$ depends on multi-factor linear modeling factors, $6 \%$ not taken into account external influencing factors.

In order to be able to compare the models with different quantities of factors and that these quantitative factors do not affect the $R^{2}$ statistic, a corrected coefficient of determination is usually used, i.e. [3]:

$$
R_{\text {текис }}^{2}=1-\frac{s^{2}}{S_{y}^{2}}
$$

In our results, the values of 0,96( $\left.Y_{1}\right)$ and 0,85 $\left(Y_{2}\right)$ of these corrected determination coefficients are derived from their proximity to $R^{2}$, which means that the change in the number of factors selected for the models assumes values around.

We use the F-criterion formula of the multifactor linear Fisher constructed 6 and 7 to verify the statistical significance and adequacy of the process under study. The actual values of the F-criterion, i.e., the first result factor $\left(Y_{1}\right) F_{\text {хисоб }}=65.933$ and the second result factor $\left(Y_{2}\right)$, are $F_{\text {хисоб }}=10.45$.

We determine the table value of the Fisher F-criterion. To do this, we determine the value from the table of the $\mathrm{F}$ criterion based on the values for the levels of freedom $k_{1}=m, k_{2}=n-m-1$ and $\alpha$ for the levels of significance. For the first outcome factor, the significance level is $\alpha=0,1$ and the freedom values are $k_{1}=2$ and $k_{2}=6-2-1=3$, with the table 


\section{Forecasting of Tourism Processes in Uzbekistan in Correlation-Regression Models}

value of the F-criterion being $F_{\text {жадвал }}=5.46$; based on the significance level $\alpha=0,1$ and the freedom levels $k_{1}=3$ and $k_{2}=6-3-1=2$ for the second outcome factor, we find that the table value of the F-criterion is $F_{\text {жадвал }}=9.16$.

Significance of these factors indicates that the values determined in $\alpha=0,1$ satisfy condition $F_{\text {account }}>F_{\text {table }}$ are statistically significant and adequate.

According to the above models 6 and 7, we forecast the number of foreign citizens visiting Uzbekistan and the number of domestic tourists. To do this, we construct simple regression models of the time-dependent trend of the factors influencing the built models.

Trend model of tourist services export:

$$
X_{1}=211.7 \cdot \mathrm{t}-115 \text {. }
$$

Trend model of the number of tour operators:

$$
X_{1}, X_{5}=72.829 \cdot t-66.07 \text {. }
$$

Trend model of the number of hotels:

$$
X_{3}==145.23 \cdot t+242.53 \text {. }
$$

Trend model of the number of places:

$$
X_{4}=17.598 \cdot t^{0.556} \text {. }
$$

We calculate the forecast values of each factor on 9-12 simple trend regression models and place their values on models 6 and 7. The results are presented in Tables 11-12 and Figure 3-4.

\begin{tabular}{|c|c|c|c|c|}
\hline Years & $\begin{array}{l}\begin{array}{l}\text { Number of domestic } \\
\text { tourists } \\
\text { (visits, } \\
\text { thousands) }\end{array} \\
\end{array}$ & Number of hotels (in units) & $\begin{array}{l}\text { Number of } \\
\text { places } \\
\text { (thousand) }\end{array}$ & Tour operators (together) \\
\hline 2014 & 4100 & 428 & 19 & 80 \\
\hline 2015 & 5700 & 514 & 24 & 91 \\
\hline 2016 & 6300 & 689 & 30 & 102 \\
\hline
\end{tabular}

Table 11. Number of foreign citizens visiting Uzbekistan (dynamics in 2014-2019 and forecast values for 2020-2030)

\begin{tabular}{|l|l|l|l|}
\hline Years & $\begin{array}{l}\text { Foreign citizens arriving in } \\
\text { Uzbekistan (thousand people) }\end{array}$ & $\begin{array}{l}\text { Export of tourist services } \\
\text { (million dollars) }\end{array}$ & $\begin{array}{l}\text { Tour operators } \\
\text { (together) }\end{array}$ \\
\hline 2014 & 2000 & 285 & 80 \\
\hline 2015 & 2010 & 324 & 91 \\
\hline 2016 & 2070 & 386 & 102 \\
\hline 2017 & 2690 & 547 & 127 \\
\hline 2018 & 5300 & 1040 & 234 \\
\hline 2019 & 6748 & 1313 & 499 \\
\hline 2020 & 7010 & 1367 & 517 \\
\hline 2021 & 8017 & 1579 & 589 \\
\hline 2022 & 9023 & 1790 & 662 \\
\hline 2023 & 10029 & 2002 & 735 \\
\hline 2024 & 11035 & 2214 & 808 \\
\hline 2025 & 12042 & 2425 & 881 \\
\hline 2026 & 13048 & 2637 & 954 \\
\hline 2027 & 14054 & 2849 & 1026 \\
\hline 2028 & 15061 & 3061 & 1099 \\
\hline 2029 & 16067 & 3272 & 1172 \\
\hline 2030 & 17073 & 3484 & 1245 \\
\hline
\end{tabular}

Table 12. Number of foreign citizens visiting Uzbekistan (dynamics in 2014-2019 and forecast values for 2020-2030) 
Forecasting of Tourism Processes in Uzbekistan in Correlation-Regression Models

\begin{tabular}{|l|l|l|l|l|}
2017 & 9800 & 772 & 39 & 127 \\
\hline 2018 & 14300 & 914 & 41 & 234 \\
\hline 2019 & 16900 & 1188 & 53 & 499 \\
\hline 2020 & 19864 & 1404 & 56 & 517 \\
\hline 2021 & 21985 & 1550 & 60 & 589 \\
\hline 2022 & 24074 & 1695 & 63 & 662 \\
\hline 2023 & 26136 & 1840 & 67 & 735 \\
\hline 2024 & 28174 & 1985 & 70 & 808 \\
\hline 2025 & 30191 & 2131 & 73 & 881 \\
\hline 2026 & 32189 & 2276 & 77 & 954 \\
\hline 2027 & 34170 & 2421 & 80 & 1026 \\
\hline 2028 & 36136 & 2566 & 82 & 1099 \\
\hline 2029 & 38089 & 2711 & 85 & 1172 \\
\hline 2030 & 40025 & 2857 & 88 & 1245 \\
\hline
\end{tabular}

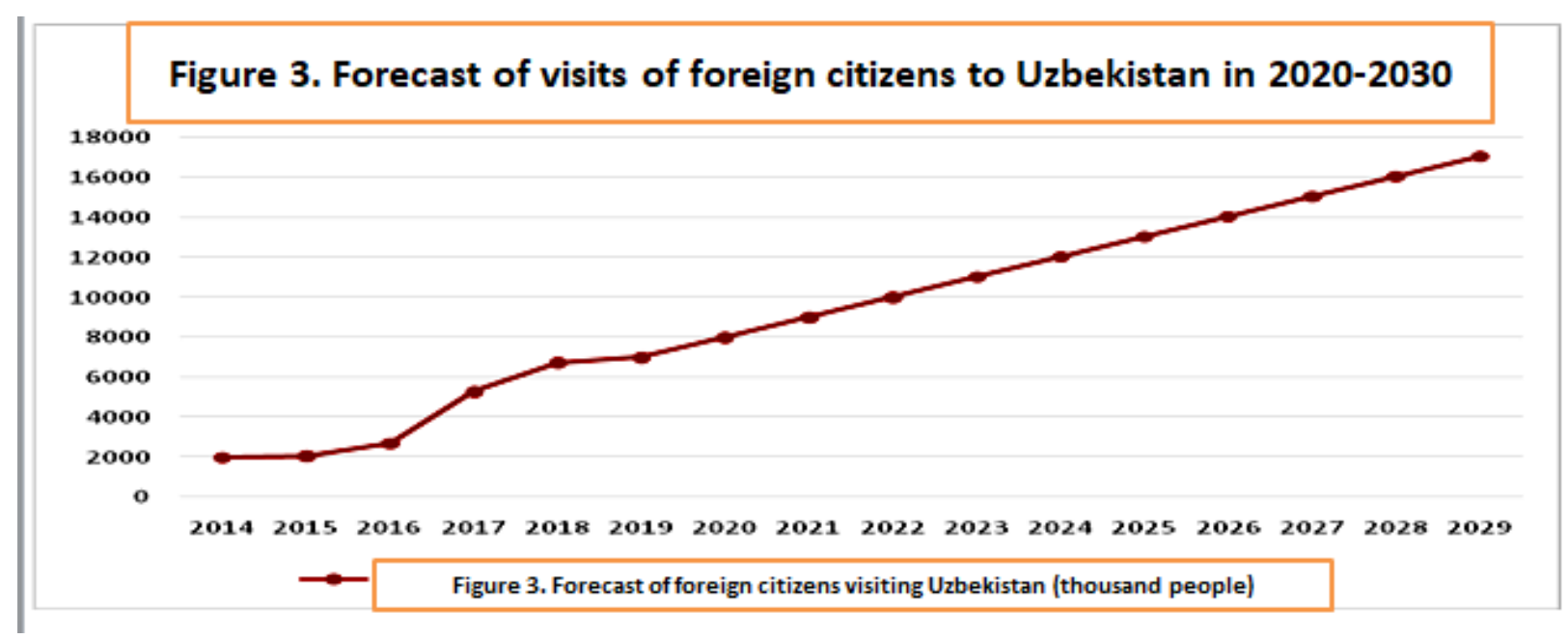

Forecast of the number of domestic tourists in Uzbekistan in 2020-2030

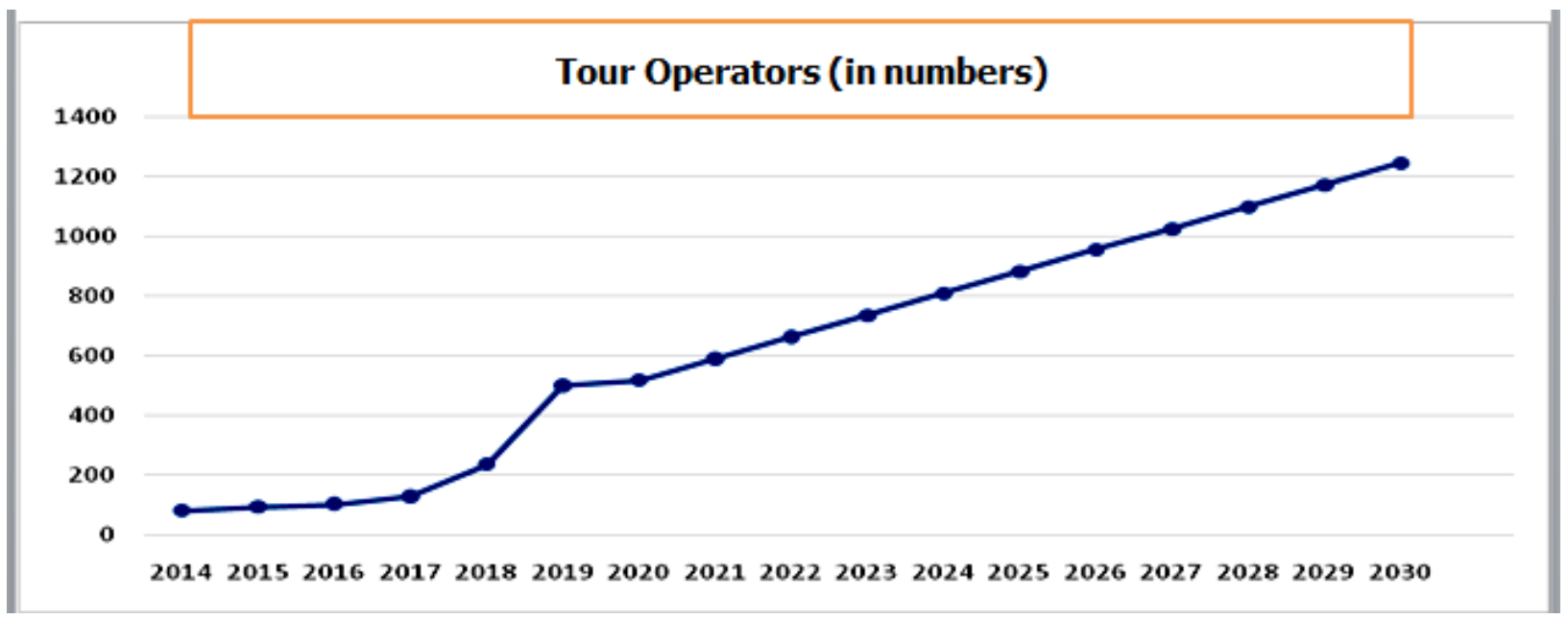


Forecasting of Tourism Processes in Uzbekistan in Correlation-Regression Models

Figure 4. Forecast of the number of tour operators in Uzbekistan for 2020-2030

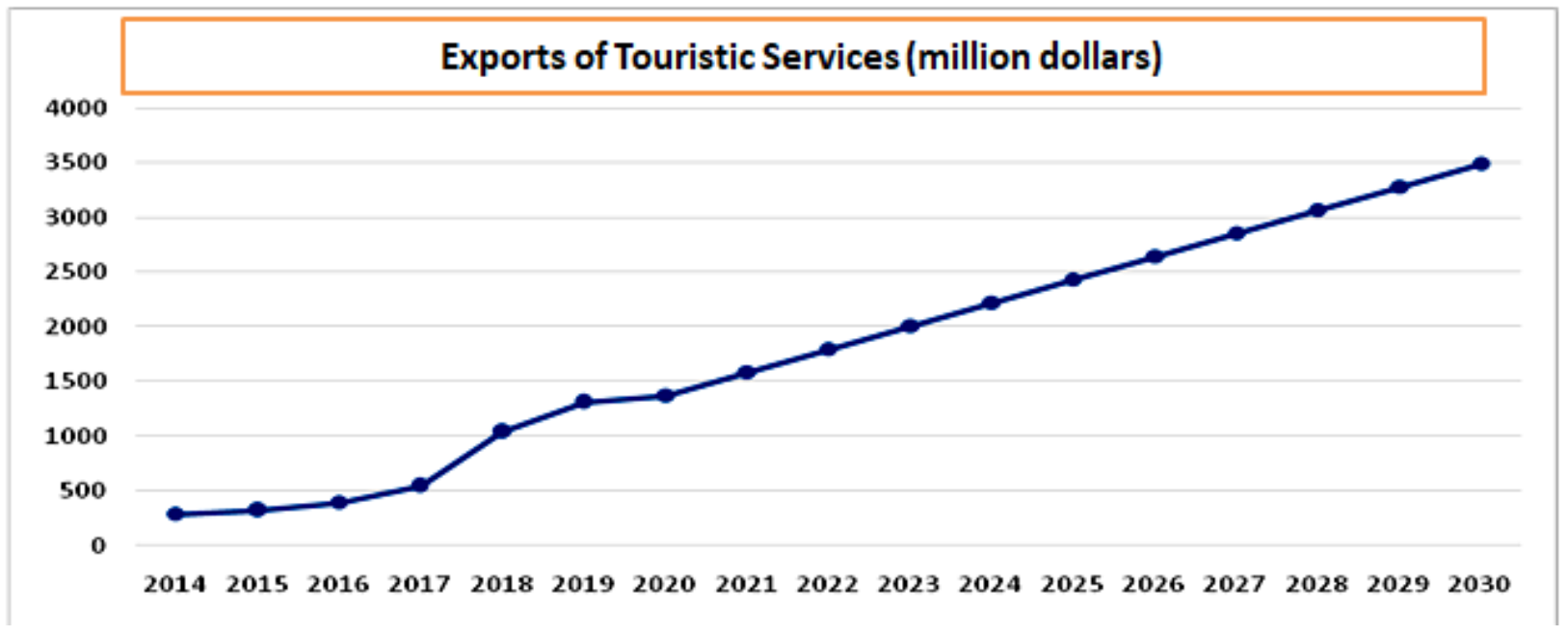

Figure 5. Forecast of tourism services exports in 2020-2030

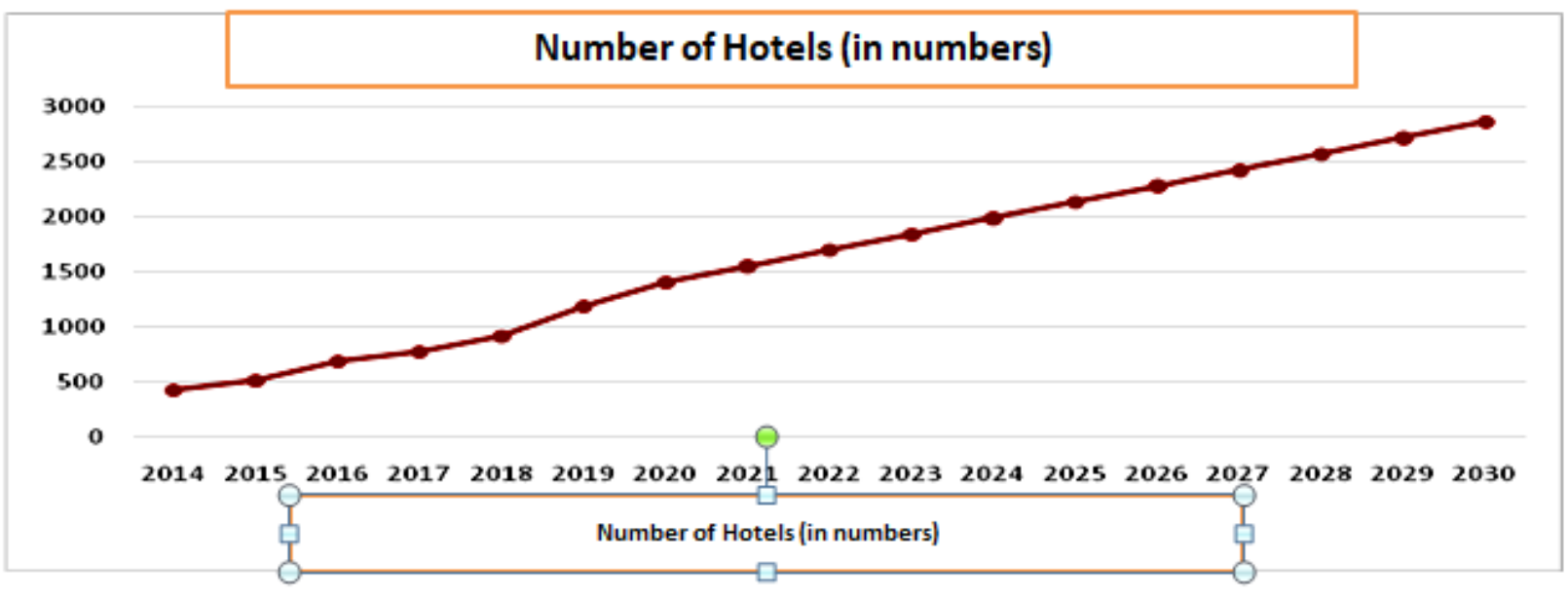

Figure 6 Forecast of the number of hotels in Uzbekistan for 2020-2030

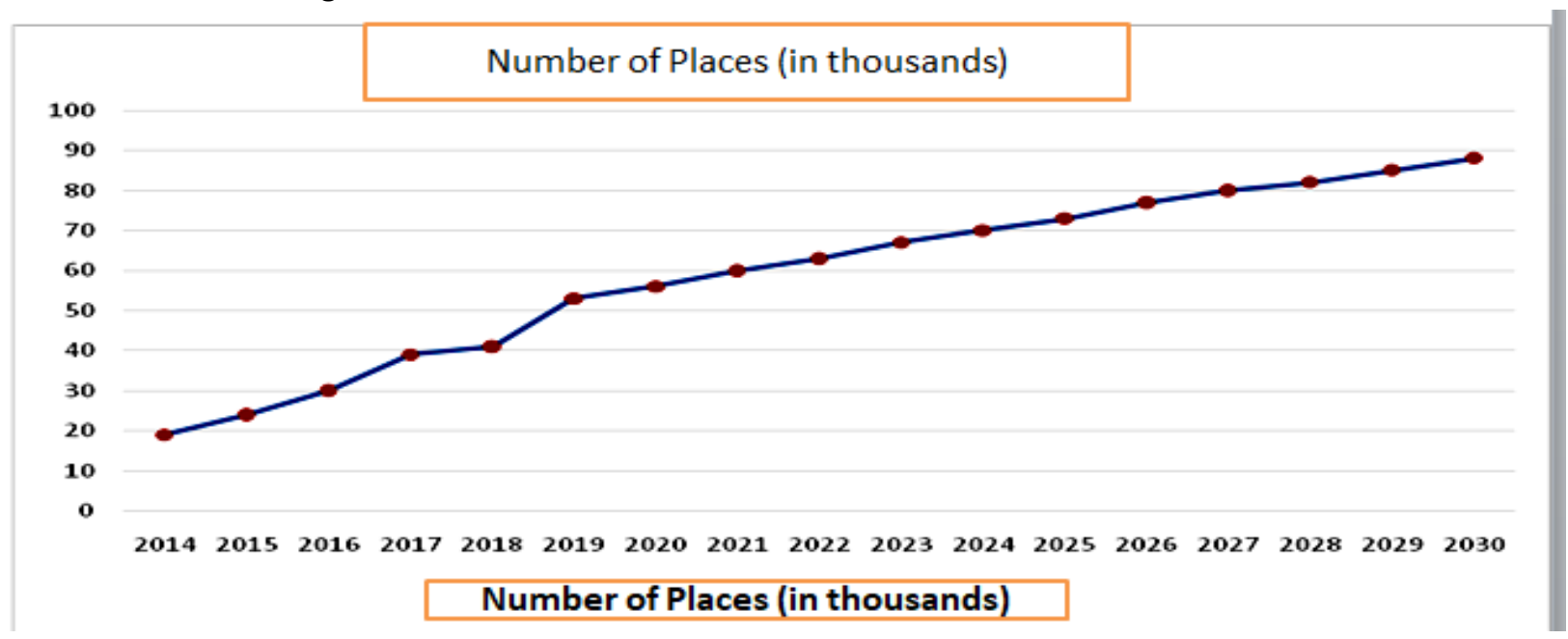

Figure 7. Forecast of the number of places in Uzbekistan in 2020-2030

\section{CONCLUSION}

In conclusion, it can be said that the built-in multivariate linear regression was found to be statistically significant when examined based on the criteria of the models, reliable when the model parameters were examined, and lack of multicollinearity. Built-in models can be suggested for use in forecasting. 


\section{Forecasting of Tourism Processes in Uzbekistan in Correlation-Regression Models}

\section{REFERENCES}

1) Alimova M.T. (2017) Development features and trends of the regional tourism market (on the example of Samarkand region). Doctor of Economical Sciences. Diss. Abstract. - Samarkand. - p. 80.

2) Alimova M.T. (2015) Forecasting demand in the international tourism market of the Republic of Uzbekistan. Marketing in Russia and abroad. - Moscow. - No. 2. - pp. 96-108.

3) Dimitrios Asteriou and Stephen G. Hall. (2007) Applied econometrics. A modern approach using Eviews and Microfit. Revised edition. Palgrave Macmillan, New York. - p. 397.

4) Eliseeva I.I. (2003) Econometrics: A Textbook. - Moscow: Finance and statistics. - p. 344.

5) Gulmurodov F.E. (2021) Improving the scientific basis of systematic mapping for tourism purposes (on the example of Samarkand region) Ph.D. (PhD) dissertation for a degree. avtoref. - Tashkent. - p. 44.

6) Kostromin A.V. (2004) Summary of lectures on the course "Econometrics". - Kazan. - p. 17. 